\title{
USO DA POLPA CÍTRICA E DO MILHO GRÃO NA ENSILAGEM DE CAPIM- ELEFANTE BRS CAPIAÇU
}

\begin{abstract}
Anna Carolina Rinco de Lemosi'; Almira Biazon França²
${ }^{1}$ Graduanda em Medicina Veterinária, Bolsista de Iniciação Científica (BIC), Universidade Federal de Juiz de Fora (UFJF), Juiz de Fora, Minas Gerais, ${ }^{2}$ Doutora em Produção Animal, Universidade

Federal de Juiz de Fora (UFJF), Juiz de Fora, Minas Gerais.
\end{abstract}

DOI: 10.47094/ICONNECA.2021/25

\section{RESUMO}

O uso do capim-elefante cv. BRS Capiaçu na ensilagem apresenta um melhor custo-benefício para os produtores rurais pela sua maior produtividade se comparado com outras forrageiras. Porém, no momento do ponto de corte da planta, há um alto teor de umidade levando a maiores perdas por efluentes e fermentações secundárias indesejadas. Uma forma de se controlar esse problema é por meio da utilização de aditivos adsorventes que vão absorver a umidade do material ensilado e aumentar o teor de matéria seca (MS), sendo a polpa cítrica e o milho grão uns dos principais aditivos utilizados.

PALAVRAS-CHAVES: Aditivos. Bovinocultura leiteira. Gramíneas tropicais.

ÁREA TEMÁTICA: Conservação de alimentos.

\section{INTRODUÇÃO}

O Capim-Elefante (Pennisetum purpureum Schum.) é uma forrageira perene com elevado potencial de produção de matéria-seca (MS), sendo muito difundido na alimentação de ruminantes (ROSA et.al, 2019). Pensando na boa aceitação do capim-elefante pelos produtores rurais, a Embrapa desenvolveu a cultivar BRS Capiaçu, visando oferecer uma forrageira de boa qualidade nutricional e elevado potencial de produção, voltada tanto para a silagem, quanto para o picado verde (PEREIRA et al., 2016).

A cultivar BRS Capiaçu, assim como as demais forrageiras tropicais, apresenta algumas características negativas para a produção de uma silagem de boa qualidade, como o baixo teor de MS e dos carboidratos solúveis no momento da colheita, além do excesso de umidade que leva a fermentações indesejáveis. O uso de aditivos adsorventes é recomendado para diminuir a umidade da forragem ensilada, o que, consequentemente, aumenta o teor de MS e reduz possíveis perdas por efluentes. 
Nesse sentido, o presente trabalho tem como objetivo fazer uma revisão de literatura abordando uso da polpa cítrica e do milho grão como aditivos adsorventes e seus efeitos na qualidade da silagem de Capim-Elefante cv. BRS Capiaçu.

\section{METODOLOGIA}

Para atender a finalidade do trabalho, considerou-se pesquisas envolvendo a silagem de capimelefante e também de sua cultivar BRS Capiaçu. Foram realizadas pesquisas bibliográficas em quatro bibliotecas virtuais: Scielo, Pubvet, Periódico Capes e Biblioteca Virtual da Embrapa. O horizonte temporal dos experimentos diretamente ligados a ensilagem de BRS Capiaçu abrangeu os anos de 2016 a 2020. Nas buscas foram empregadas as palavras-chave: "capim-elefante", "BRS Capiaçu", "aditivos adsorventes", "silagem", "polpa cítrica" e "farelo de milho".

\section{FUNDAMENTAÇÃO TEÓRICA}

A BRS Capiaçu é 30\% mais produtiva do que as outras cultivares de Pennisetum purpureum atingindo em média $100 \mathrm{t} / \mathrm{ha} /$ corte de matéria verde (MV), representando três vezes mais do que o milho e o sorgo e sendo uma boa alternativa como alimentação para os ruminantes, porém, o valor de matéria seca (MS) durante a colheita, principalmente de plantas com idade entre 60 e 90 dias, geralmente se encontra abaixo de $20 \%$, distante do ideal que seria de $28 \%$ a $34 \%$ (RETORE et al., 2020).

Uma forma de aumentar o teor de MS e os carboidratos solúveis, e reduzir a perda por efluentes, é a utilização de aditivos adsorventes como, por exemplo, produtos processados da polpa cítrica e do milho (milho grão triturado, fubá de milho).

A polpa cítrica é destaque como aditivo adsorvente apresentando alto teor de MS e de carboidratos solúveis, capacidade de reduzir a umidade do material ensilado, elevado valor nutritivo e boa aceitabilidade pelos animais.

Em um experimento feito na UNIFENAS, foi observado que ao utilizar 20\% de polpa cítrica na silagem de capim-elefante cv. Cameroon, houve um incremento de 54,07\% no valor da MS, ficando por volta de $26,50 \%$. Sem a adição de polpa cítrica o valor era de 17,20\% de MS (PEREIRA et al. 1999).

A inclusão em níveis crescentes (de 0\% a 15\%) de polpa cítrica na silagem de capim-elefante Napier em um experimento feito no Departamento de Nutrição e Produção Animal da Faculdade de Medicina Veterinária e Zootecnia da Universidade de São Paulo (Campus de Pirassununga$\mathrm{SP}$ ), mostrou um aumento linear na MS da silagem, onde silagens sem adição de polpa cítrica apresentaram 20,61\% de MS e silagens com adição de 15\% de polpa cítrica apresentaram $28,43 \%$ de 
Em relação ao uso de polpa cítrica em silagens de BRS Capiaçu, estudos não foram encontrados durante a pesquisa para essa revisão literária.

O milho moído é outro produto que pode ser utilizado como aditivo adsorvente, apresentando teor de MS maior do que $85 \%$, e alta capacidade de reter umidade na forma de fubá (PAULA et al., 2020).

Observou-se que com a adição de $10 \%$ de fubá de milho nas silagens de BRS Capiaçu, o teor de MS superou 25\% e a redução nas perdas por efluentes foi diretamente proporcional ao aumento na quantidade de fubá de milho adicionada. Foi indicado, portanto, a inclusão de valores acima de $10 \%$ de fubá de milho para melhorar o valor nutritivo das silagens de capim-elefante BRS Capiaçu (PAULA et al., 2020).

No experimento desenvolvido na Embrapa Agropecuária Oeste em parceria com a Universidade Federal da Grande Dourados, em Dourados, MS, a adição de 15\% de milho grão triturado em uma silagem de BRS Capiaçu, cortado entre 60 e 90 dias de idade, elevou o valor da MS próximo ao ideal para uma silagem de boa qualidade, ficando em torno de $26 \%$. Já na silagem formada por um capim de colheita mais tardia, aos 120 dias, o valor ideal de MS foi atingido, ficando acima de $30 \%$. Concluise que a adição de, no mínimo, $15 \%$ de milho grão triturado é essencial para o melhor aproveitamento de silagens de BRS Capiaçu com 60 dias de idade (RETORE et al., 2020).

\section{CONSIDERAÇÕES FINAIS}

A utilização de aditivos adsorventes auxilia no aumento da qualidade de silagens de capimelefante BRS Capiaçu, sendo que estudos corroboram com a adição mínima de $10 \%$ de fubá de milho e 15\% de milho grão triturado. Mais estudos são necessários para definir o valor de adição de polpa cítrica, apesar de já ser comprovada sua eficácia na melhoria da qualidade de silagens feitas com outras cultivares de capim-elefante.

\section{PRINCIPAIS REFERÊNCIAS}

PAULA, R.P et al. Composição bromatológica da silagem de capim- elefante BRS Capiaçu com inclusão fubá de milho. Revista PUBVET, Maringá, v.14, n.10, a680, p.1-11, 2020.

PEREIRA, R.C et al. Adição de polpa cítrica peletizada na ensilagem de capim - elefante (Pennisetum purpureum Schum) cv. Cameroon. Revista da Universidade Alfenas, v.5, p.147-152, 1999.

PEREIRA, A.V et al. BRS Capiaçu: cultivar de capim-elefante de alto rendimento para produção de silagem.). Juiz de Fora, MG, Embrapa Gado de Leite. out. 2016 (Embrapa Gado de Leite. 
Comunicado Técnico 79).

RETORE, M et al. Qualidade da Silagem do Capim-Elefante BRS Capiaçu. Dourados, Embrapa Agropecuária Oeste. dez. 2020 (Embrapa Agropecuária Oeste. Comunicado Técnico 261).

RODRIGUES et al. Efeito da Adição de Níveis Crescentes de Polpa Cítrica sobre a Qualidade Fermentativa e o Valor Nutritivo da Silagem de Capim-Elefante. Revista Brasileira de Zootecnia, Viçosa, v.34, n.4, p.1138-1145, 2005.

ROSA, P.P et al. Características do Capim Elefante Pennisetum purpureum (Schumach) e suas novas cultivares BRS Kurumi e BRS Capiaçu. Pesquisa Agropecuária Gaúcha, Porto Alegre, v.25, ns.1/2, p. 70-84, 2019. 